\title{
Assessment of Pharmacological Properties of Hydroethanolic Extract of Bixa orellana (Bixaceae) Leaves on Acetic Acid-induced Colitis in Rat
}

\section{Michel Archange Fokam Tagne ( $\nabla$ fm_archange@yahoo.fr )}

Universite de Ngaoundere Faculte des Sciences https://orcid.org/0000-0002-4145-9788

\section{Blaise Kom}

Universite de Ngaoundere Faculte des Sciences

\section{Angèle Foyet Fondjo}

Higher Institute of Applied Sciences, University Institute of Gulf of Guinea

\section{Paul Aimé Noubissi}

University of Buea

\section{Estelle Flora Gaffo}

Universite de Ngaoundere Faculte des Sciences

\section{Gaëtan Olivier Fankem}

University of Yaounde I: Universite de Yaounde I

Henri Wambe

University of Dschang Faculty of Sciences: Universite de Dschang Faculte des Sciences

\section{Joseph Ngakou Mukam}

University of Yaounde I: Universite de Yaounde I

\section{René Kamgang}

University of Yaounde I: Universite de Yaounde I

\section{Jean-Louis Essame Oyono}

Laboratory of Endocrinology and Radioisotopes, Institute of Medical Research and Medicinal Plants

Studies (IMPM), Yaoundé

\section{Research Article}

Keywords: Bixa orellana, Ulcerative colitis, Oxidative stress, Hematology, Histology

Posted Date: August 23rd, 2021

DOI: https://doi.org/10.21203/rs.3.rs-796285/v1

License: (c) (1) This work is licensed under a Creative Commons Attribution 4.0 International License.

Read Full License 



\section{Assessment of pharmacological properties of hydroethanolic extract of Bixa orellana (Bixaceae) leaves on acetic acid-induced colitis in rat}

Michel Archange Fokam Tagne, ${ }^{1 *}$, Blaise $\mathrm{Kom}^{2}$, Angèle Foyet Fondjo ${ }^{3}$, Paul Aimé Noubissi ${ }^{4}$, Estelle

Flora Gaffo $^{1}$, Gaëtan Olivier Fankem ${ }^{5}$, Henri Wambe ${ }^{6}$, Joseph Ngakou Mukam $^{5}$, René Kamgang ${ }^{5,7}$,

Jean-Louis Essame Oyono ${ }^{7}$

${ }^{1}$ Department of Biological Sciences, Faculty of Science, University of Ngaoundere, Cameroon.

${ }^{2}$ Department of Chemistry, Faculty of Science, University of Ngaoundere, Cameroon

${ }^{3}$ Department of Applied Sciences for Health, Higher Institute of Applied Sciences, University Institute of

Gulf of Guinea, Cameroon.

${ }^{4}$ Department of Zoology and Animal Physiology, Faculty of Science, University of Buea, Cameroon.

${ }^{5}$ Animal Physiology Laboratory, Faculty of Science, University of Yaoundé I, Cameroon.

${ }^{6}$ Department of Biological Sciences, Faculty of Science, University of Dschang, Cameroon.

${ }^{7}$ Laboratory of Endocrinology and Radioisotopes, Institute of Medical Research and Medicinal Plants studies (IMPM), Yaoundé, Cameroon.

Correspondence: Michel Archange Fokam Tagne.

P.O. Box 454 Ngaoundere, Cameroon;

Email: fm_archange@yahoo.fr; fmarchange@gmail.com; fokam.tagne@univ-ndere.cm Phone: +237697589275

ORCID iD: 0000-0002-4145-9788 


\begin{abstract}
Ulcerative colitis is one of the inflammatory bowel diseases that is increasing in incidence worldwide. The objective of this work was to evaluate the activities of the hydroethanolic extract of the leaves of Bixa orellana on colitis in rats. Thirty-six rats were anesthetized with ether after 18 hours of fasting and ulcerative colitis was induced by intrarectal administration of $1 \mathrm{~mL}$ of acetic acid $(5 \%)$ in all animals except the normal control group which received instead distilled water $(1 \mathrm{~mL}) .48$ hours after induction, the normal control and the negative control received distilled water $(10 \mathrm{~mL} / \mathrm{kg})$, the positive control received loperamide $(5 \mathrm{mg} / \mathrm{kg})$ and three test groups received hydroethanolic extract Bixa orellana leaves at 100, 200 and $400 \mathrm{mg} / \mathrm{kg}$ per day for seven days. Administration of the extract significantly $(\mathrm{P}<0.01)$ reduced the number of diarrheal stools, nitric oxide and malonedialdheide levels, anemia and the number of colon lesions. The extract significantly $(\mathrm{P}<0.01)$ improved body weight loss as well as antioxidant parameters (superoxide dismutase, catalase, gluthation). These results would justify the use of Bixa orellana in the treatment of inflammatory bowel disease.
\end{abstract}

Key words: Bixa orellana, Ulcerative colitis, Oxidative stress, Hematology, Histology 


\section{Introduction}

Chronic Inflammatory Bowel Diseases (IBD) are conditions characterized by inflammatory lesions of the digestive tract, dominated by Ulcerative Colitis (UC) and Crohn's Disease (CD) (Kozembrou Ngueto Kitte 2019). Colitis, known as irritable bowel syndrome or functional colopathy, manifests itself with various symptoms such as, intestinal pain, fever, general fatigue, loss of appetite, anemia (Rufo and Bousvaros 2006; Freeman 2014), weight loss and diarrhea characterized by loose, semi-liquid or watery and bloody stools (Ammoury and Ghishan 2012). The incidence and prevalence of these conditions have increased dramatically over the past fifty years worldwide. In France, the number of cases of UC and UC rose respectively from 14 to 200 per 100,000 inhabitants and from 15 to 200 per 100,000 inhabitants (Cosnes et al. 2011). In Cameroon, the frequency of hemorrhoidal diseases is estimated at $40.83 \%$ of lower digestive pathologies (Ankouane Andoulo et al. 2013). Hemorrhoids are the main causes of colorectal cancer in Cameroon with an increasing prevalence (Ankouane Andoulo et al. 2013).

IBD is usually caused by bowel disturbances, physical inactivity, unbalanced, low-fiber, high-residue, and heavily spicy diet, alcohol, tobacco, coffee, and constipation. IBD creates a certain imbalance in the body of patients, responsible for oxidative stress and the weakening of the intestinal immune defense system (Dibong et al. 2015). These diseases reduce the quality of life and work capacity and increase the disability of the world's population (Cosnes et al. 2011). These IBD can be cured spontaneously or with treatment based on steroidal and non-steroidal anti-inflammatory drugs, 5-aminosalycilates, corticosteroids, immunomodulators, anti-TNF antibodies and by surgery in the event of complications or resistance to medical treatment (Rufo and Bousvaros 2006). These molecules, although effective, are associated with deleterious effects such as digestive damage and liver and kidney toxicities (Yougbaré-Ziébrou et al. 2016). Notwithstanding the progress of conventional medicine, the treatment of these pathologies remains unsatisfactory because of the high cost of modern practices, the undesirable side effects of drugs, as well as the lack of advanced health infrastructure. More than $70 \%$ of patients with inflammatory bowel disease use complementary and alternative medicine (Lee et al. 2018). These shortcomings of modern medicine push populations to resort to traditional medicine (Dibong et al., 2015), which is less expensive; less toxic and available and which uses medicinal plants.

Medicinal plants help strengthen health programs, as well as the country's economy (Ancheta Henríquez and Guzmán Santamaría 2011). Bixa orellana is a medicinal plant that has antioxidant, anti-inflammatory, antimicrobial, analgesic and hypoglycemic activities (Gupta 2016) and is used in the treatment of vomiting, wounds, headaches and diarrhea (Fokam Tagne et al. 2019). Several traditional recipes have been shown to be effective in the treatment of inflammatory pathologies (Yougbaré-Ziébrou et al. 2016), but very little data are available to anti-hemorrhoidal plants in Africa and in Cameroon in particular. This leads us to focus on the enhancement of plant species used in complementary and alternative medicine to treat the inflammatory bowel diseases, which until now their effectiveness is uncertain (Lee et al. 2018). The objective of this work was to evaluate the properties of Bixa orellana hydroethanolic extract on acetic acid-induced ulcerative colitis in rats.

\section{Materials and methods}

\subsection{Plant material and extraction}


Bixa orellana leaves were harvested in June 2020 between 8 a.m. and 10 a.m. on the campus of the University of Ngaoundéré (Vina Division, Adamawa Region, Cameroon). This plant was identified by comparison with a reference voucher, registered number 14099/SRF.Cam at the National Herbarium of Cameroon. B. orellana leaves were washed with tap water to remove dust, dried in the shade room temperature and then pulverized. The dried leaves were then crushed and the resulting powder was saved for extraction.

Two hundred grams (200 g) of B. orellana leaves powder were macerated in $2000 \mathrm{~mL}$ of ethanol/distilled water $(1 \mathrm{~V} / 4 \mathrm{~V})$ for $72 \mathrm{~h}$. The macerate was filtered through Wathman filter paper No. 3, then concentrated in a rotary evaporator and oven dried at $40^{\circ} \mathrm{C}$. After drying, the hydroethanolic extract of $B$. orellana was weighed and the yield was determined by the following formula:

$$
\text { Yield }(\%)=\frac{\text { Mass of plant extract }(\mathrm{g})}{\text { Mass of plant powder (g) }} * 100(1)
$$

Forty-three grams (43 g) of brown extract was obtained, yielding $21.50 \%$.

\subsection{Experimental animals}

Thirty-six (36) female Wistar albino rats, 9 to 10 weeks old and weighing between 165 and 180 g, were used for the experiment. In vivo experiments were performed in accordance with European Union guidelines for the protection of animals (EEC Council 86/609) (Smith et al. 2007). Before the experiment, the rats were acclimatized for a week in the laboratory where the temperature was approximately $22 \pm 2{ }^{\circ} \mathrm{C}$ with a light / dark cycle of $12 / 12 \mathrm{~h}$. The diet consisted of a mixture of corn flour (60\%), wheat (10\%), fish (12\%), soy flour (15\%) and palm oil (3\%) (Kamgang et al. 2008).

\subsection{Induction of colitis and treatment of animals}

Before the start of the experiment, thirty six female Wistar albino rats, divided into six (6) groups of six (6) animals each, were fasted for eighteen (18) hours with free access to the water. Colitis was induced by the method of Thippeswamy et al. (Thippeswamy et al. 2011) with some modifications. All animals were then anesthetized with ether and each animal received rectally $1 \mathrm{~mL}$ of acetic acid $(5 \%$, v/v) solution except for the normal control group which received $1 \mathrm{~mL}$ of distilled water instead. After administration, the rats were kept in an upright position for 30 seconds to limit reflux of the acetic acid solution or distilled water (Fokam Tagne et al. 2021a; Fokam Tagne et al. 2021b). The animals were observed for forty eight hours for the establishment of colitis. Forty-eight (48) hours after induction of colitis the animals were treated with B. orellana hydroethanolic extract, loperamide or distilled water. Oral administration of these treatments was performed twice a day $(6$ a.m. and 6 p.m.) for seven days as:

$>$ Group I (normal control: NC) received $10 \mathrm{~mL} / \mathrm{kg}$ of distilled water;

$>$ Group II (colitis control: $\mathrm{CC}$ ) received $10 \mathrm{~mL} / \mathrm{kg}$ of distilled water;

$>$ Group III (positive control: Lop5) received $5 \mathrm{mg} / \mathrm{kg}$ of loperamide (Imodium);

> Group IV (Bo100) received $100 \mathrm{mg} / \mathrm{kg}$ of B. orellana hydroethanolic extract;

$>$ Group V (Bo200) received $200 \mathrm{mg} / \mathrm{kg}$ of B. orellana hydroethanolic extract;

$>$ Group VI (Bo400) received $400 \mathrm{mg} / \mathrm{kg}$ of B. orellana hydroethanolic extract. 
During treatment, the number and quality of diarrheal stools, animal behavior and weight change were assessed and recorded daily. At the end of the treatment, the animals were fasted for 18 hours with free access to water. They were then weighed, anesthetized and sacrificed by cervical dislocation. Part of the blood was collected in EDTA tubes for hematological analyzes and another part was collected in dry tubes and then centrifuged at 3000 rpm for 15 minutes, for analyzes of oxidative stress parameters. The colon was removed, emptied of its contents, weighed and the length measured with a tape measure, which allowed us to determine the linear weight of the colon according to the formula:

$$
\text { Linear weight }(\mathrm{mg} / \mathrm{mm})=\frac{\text { Mass of emptied colon }}{\text { Colon length }}(2)
$$

The liver, kidneys, spleen and colon were removed, rinsed with physiological water; each organ was weighed. The relative weight $(\mathrm{RW})$ of the different organs was calculated according to the formula:

$$
R W(\%)=\frac{\text { Organ weight }(\mathrm{g})}{\text { Body weight }(\mathrm{g})} * 100(3)
$$

Part of the distal colon and part of the liver were stored in buffered formalin $(10 \%, \mathrm{v} / \mathrm{v})$ solution for histological sections.

For the preparation of the different organ homogenates, $0.5 \mathrm{~g}$ of each organ was ground using a ceramic mortar and pestle on an ice tray. $2.5 \mathrm{~mL}$ of Tris buffer was added to each ground material and the mixture was transferred to dry test tubes, then centrifuged at $3000 \mathrm{rpm}$ for 25 minutes and the obtained supernatant was collected. The homogenates and sera obtained were stored at $-20^{\circ} \mathrm{C}$ for the evaluation of biochemical parameters.

\subsection{Assays of biochemical parameters of oxidative stress}

\subsubsection{Assessment of superoxide dismutase (SOD) activity}

$134 \mu \mathrm{L}$ of sample and $1800 \mu \mathrm{L}$ of carbonate buffer $(0.05 \mathrm{M}, \mathrm{pH} 10.2)$ were introduced into the test tubes and the blank tube, respectively. $1666 \mu \mathrm{L}$ of carbonate buffer were then added into the test tubes. The reaction was started by adding $200 \mu \mathrm{L}$ of adrenaline $(0.3 \mathrm{mM})$ to each tube. The absorbance of the test tubes was measured at 20 and 80 seconds against the blank at $480 \mathrm{~nm}$ (Misra and Fridovich 1972). The specific activity of SOD was determined as follows:

$$
\operatorname{Inhibition}(\%)=100-\frac{(\mathrm{Ab} 20 \mathrm{~s}-\mathrm{Ab} 80 \mathrm{~s}) \text { test }}{(\mathrm{Ab} 20 \mathrm{~s}-\mathrm{Ab} 80 \mathrm{~s}) \mathrm{blank}} * 100 \%(4)
$$

Where: Ab20s: Absorbance measured at 20 seconds; Ab80s: Absorbance measured at 80 seconds;

\subsubsection{Assessment of catalase activity}

In the presence of catalase, hydrogen peroxide is broken down and the residue binds to potassium dichromate to form an unstable blue-green precipitate of Perchloric acid, which is decomposed by heat to form a green complex (Sinha 1972).

$50 \mu \mathrm{L}$ of sample and $50 \mu \mathrm{L}$ of distilled water were introduced in the test tubes and in the blank tube, respectively. $750 \mu \mathrm{L}$ of phosphate buffer saline $(0.1 \mathrm{mM}$; pH 7.5) and $200 \mu \mathrm{L}$ of hydrogen peroxide $(50 \mathrm{mM})$ were then added to all the tubes at room temperature for one minute and the reaction was stopped by addition of $2000 \mu \mathrm{L}$ of dichromate/glacial acetic acid $(5 \%, \mathrm{v} / \mathrm{v})$. The solutions were heated at $100^{\circ} \mathrm{C}$ for 10 minutes and after 
cooling the absorbance was read against the blank at $570 \mathrm{~nm}$. The specific activity of catalase was determined from the following formula:

$$
\text { Catalase activity (mM H2O2 / } \mathrm{min} / \mathrm{g})=\frac{(\mathrm{AbTest}-\mathrm{AbBlank})}{a * t * O w}(5)
$$

Where, Ab: Absorbance; a: Slope of the calibration curve (0.0007); t: reaction time (1 min); Ow: Organ weight (g).

\subsubsection{Determination of colonic and blood GSH contents}

$100 \mu \mathrm{L}$ of sample and $100 \mu \mathrm{L}$ of Tris- $\mathrm{HCl}$ buffer $(50 \mathrm{mM}$; pH 7.4) were introduced into the test tubes and the blank tube, respectively. $1500 \mu \mathrm{L}$ of Ellman's reagent (dinitro-2,2'-dithio-5,5'-dibenzoic acid) was then added to each tube. The mixture was incubated with shaking for 60 minutes at room temperature and the absorbances were read against the blank at $412 \mathrm{~nm}$ (Ellman 1959). The concentration of reduced glutathione was determined by the following formula:

$$
[G S H](\mathrm{mol} / \mathrm{g} \text { of organs })=\frac{(\text { AbTest-AbBlank })}{(\varepsilon * \mathrm{~L} * \text { Ow })}(6)
$$

Where, $\mathrm{Ab}=$ Absorbance; $\mathrm{L}=$ Optical path $(1 \mathrm{~cm}) ; \varepsilon=$ Molar extinction coefficient $\left(13600 \mathrm{Mol}^{-1} \cdot \mathrm{cm}^{-1}\right) ; \mathrm{Om}^{2}=$ Organ weight $(\mathrm{g})$.

\subsubsection{Determination of Malondialdehyde (MDA) concentration}

$125 \mu \mathrm{L}$ of trichloroacetic acid $(20 \%, \mathrm{v} / \mathrm{v})$ and $250 \mu \mathrm{L}$ of thiobarbituric acid $(0.67 \%, \mathrm{v} / \mathrm{v})$ were added to test tubes containing $250 \mu \mathrm{L}$ of sample and to the blank tube containing $250 \mu \mathrm{L}$ of Tris- $\mathrm{HCl}$ buffer (50 mM; pH 7.4). All tubes were sealed with glass beads, heated at $90^{\circ} \mathrm{C}$ in a water bath for 10 minutes, then cooled in tap water and centrifuged at $3000 \mathrm{rpm}$ at room temperature for 15 minutes. The optical densities of the various supernatants of the test tubes were read at $530 \mathrm{~nm}$ against the blank (Wilbur et al. 1949). The concentration of MDA was determined by the formula below:

$$
[\text { MDA }](\mathrm{mol} / \mathrm{g} \text { of organs })=\frac{\Delta \mathbf{O D}}{\varepsilon \times \mathbf{L} \times \mathbf{O w}}(7)
$$

Where, [MDA]: MDA concentration; $\triangle \mathrm{OD}$ : ODtest - ODblank; L: Optical path $(1 \mathrm{~cm})$; $\varepsilon$ : Molar extinction coefficient $\left(15600 \mathrm{Mol}^{-1} . \mathrm{cm}^{-1}\right)$; Ow: organ weight $(\mathrm{g})$.

\subsubsection{Determination of nitric oxide (NO) concentration}

$100 \mu \mathrm{L}$ of sample diluted in $400 \mu \mathrm{L}$ of distilled water and $500 \mu \mathrm{L}$ of distilled water were introduced respectively into the test tubes and into the white tube. $500 \mu \mathrm{L}$ of Griess reagent was then added to each tube. The mixture was homogenized and incubated at room temperature, protected from light, for 10 minutes and the absorbance was read against the blank at $546 \mathrm{~nm}$ (Fermor et al. 2001). The concentration of NO was calculated using the following formula:

$$
[N O]=\frac{\text { ODtest }- \text { ODblank }}{a * O w}(8)
$$

Where, [NO]: Nitric oxide concentration, OD: Optical density; a: Slope of the calibration curve (1.4183); Ow: organ weight 


\subsection{Hematological analyzes}

Hematologic, leukocyte and platelet parameters were evaluated in whole blood using an automatic device (Mindray BC 20s n series TK 65000803).

\subsection{Histological analysis}

Histological analysis was carried out according to the steps: fixation, recutting, dehydration, inclusion, section, staining, mounting and observation.

\subsection{Statistical analysis}

Statistical analysis of the data obtained was performed using GraphPad Prism 8.0.1 software. Data comparison was made using the ANOVA test followed by Tukey's multiple comparison post-test and the differences were considered significant at the $5 \%$ level.

\section{Results}

\subsection{Animal behavior and appearance of stool}

A few minutes after administration of the acetic acid (5\%), the animals remained less mobile, calm, and folded over themselves with erect hairs. The test animals treated with the extract or with loperamide gradually regained their mobility during the treatment. The first bloody and/or mucous diarrheal stools appeared within the third hour after induction of colitis. In normal controls, no diarrheal stool was recorded. In the other groups given acetic acid, the number of diarrheal stools, increased significantly $(\mathrm{P}<0.01)$ from day 1 to day 7 of treatment in the colitis control and from day 1 to day 3 in rats treated with the extract at $400 \mathrm{mg} / \mathrm{kg}$ (Fig. 1).

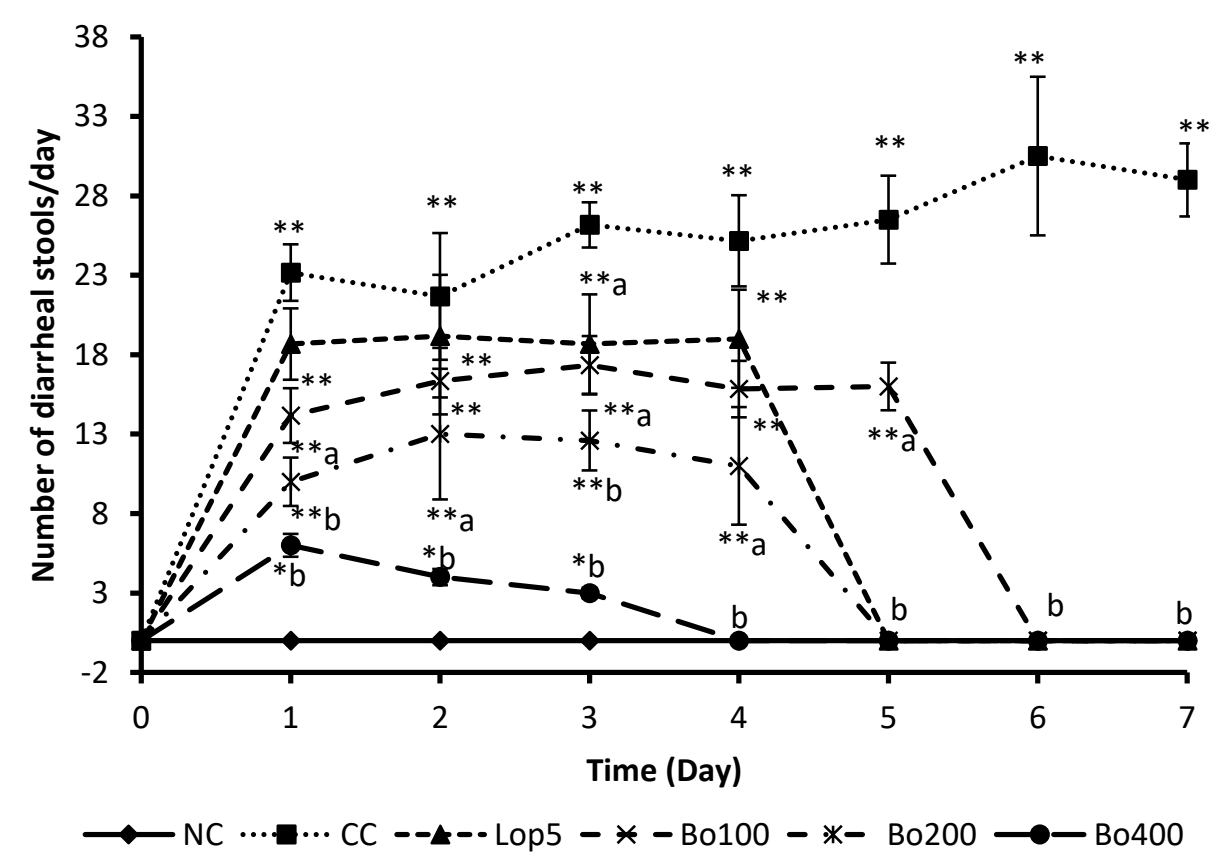

Fig. 1: Frequencies of diarrheal stools in normal rats (NC), colitis control (CC) and rats treated with loperamide (Lop5) and with hydroethanolic extract of Bixa orellana at 100 (Bo100), 200 (Bo200) and 400 (Bo400) mg/kg 
bw. $\mathrm{n}=6$. Significant difference: ${ }^{*} \mathrm{P}<0.05 ;{ }^{* *} \mathrm{P}<0.01$ between $\mathrm{NC}$ and other groups; ${ }^{\mathrm{P}} \mathrm{P}<0.05$; ${ }^{\mathrm{b}} \mathrm{P}<0.01$ between $\mathrm{CC}$ and treated groups.

\subsection{Effect of hydroethanolic extract of Bixa orellana leaves on body weight gain}

24 hours after induction, we observed weight loss in all animals given acetic acid. Normal animals have a regular body weight change throughout the treatment period while in colitis controls and treated animal's body weight decreased significantly ( $\mathrm{P}<0.01$ ) during treatment (Fig. 2).

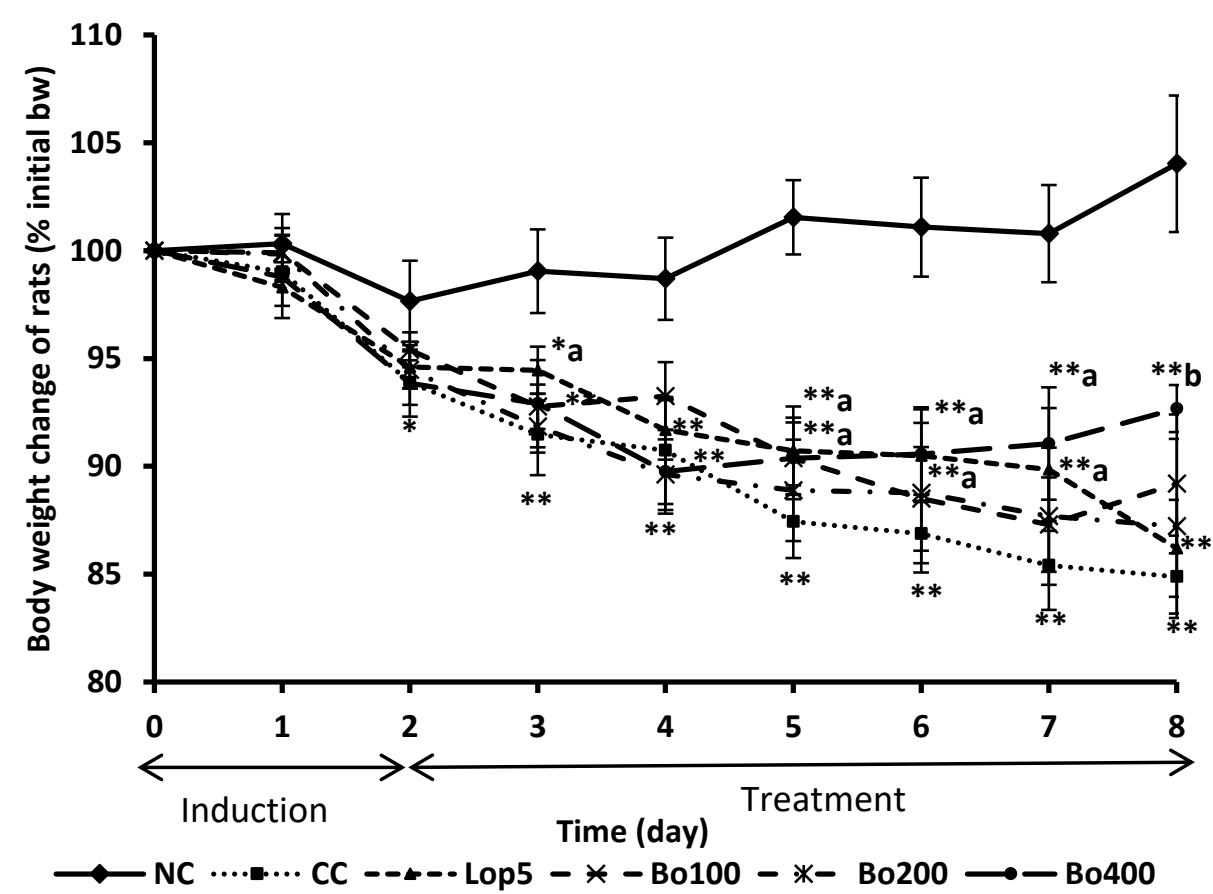

Fig. 2: Body weight change (\%) in normal rats (NC), the colitis control (CC) and rats treated with loperamide (Lop5) and with hydroethanolic extract of Bixa orellana at 100 (Bo100), 200 (Bo200) and 400 (Bo400) mg/kg bw. $\mathrm{n}=6$. Significant difference: ${ }^{*} \mathrm{P}<0.05 ;{ }^{* *} \mathrm{P}<0.01$ between $\mathrm{NC}$ and other groups; ${ }^{\mathrm{P}}<0.05$; ${ }^{\text {b }}<0.01$ between $\mathrm{CC}$ and treated groups.

\subsection{Effect of the hydroethanolic extract of Bixa orellana leaves on linear mass and colonic ulcerations in rats}

The colon of normal rats showed no ulceration. The gross lesion score for the colitis control was found to be 14.50 \pm 0.52 . The hydroethanolic extract of Bixa orellana and loperamide treated alone decrease significantly ( $P$ $<0.01)$ the gross lesion score of the colon compared to the colitis control group (Fig. 3A). The linear colon weight increased significantly $(\mathrm{P}<0.01)$ in the colitis control and the group treated with the extract at $100 \mathrm{mg} / \mathrm{kg}$ bw (Fig. 3B). 

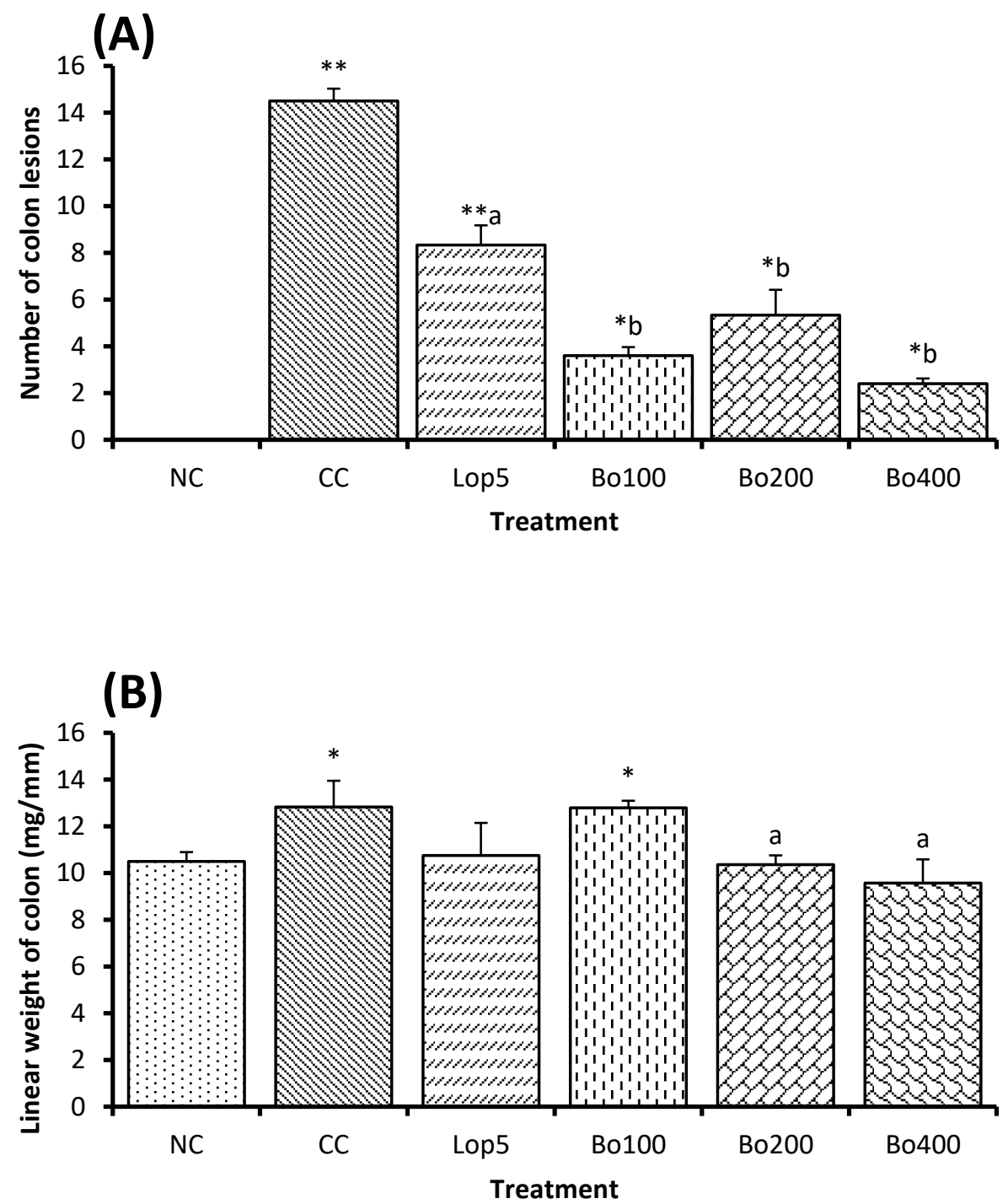

Fig. 3: Number of colon lesions (A) and linear weight (B) of the colon in normal rats (TN), the colitis control (TC) and rats treated with loperamide (Lop5) and hydroethanolic extract of Bixa orellana at doses 100 (Bo100), 200 (Bo200) and 400 (Bo400) $\mathrm{mg} / \mathrm{kg}$ bw. $\mathrm{n}=6$. Significant difference: ${ }^{*} \mathrm{P}<0.05 ;{ }^{* *} \mathrm{P}<0.01$ between $\mathrm{NC}$ and other groups; ${ }^{\text {a }}<0.05$; ${ }^{\text {b }}<0.01$ between $\mathrm{CC}$ and treated groups.

\subsection{Effect of hydroethanolic extract of Bixa orellana leaves on the relative weights of kidneys, liver and spleen}

The relative liver mass decreased significantly $(\mathrm{P}<0.05)$ only in the animals treated with the extract at the dose of $400 \mathrm{mg} / \mathrm{kg}$ compared to the normal control and the colitis control (Fig. 4A). In all rats, no significant variation was observed in the relative weights of the left and right kidneys. The relative colon mass significantly increased in all animals given acetic acid compared to the normal control. In the spleen, the relative weight significantly (P $<0.01)$ decreased in all the animals that received acetic acid compared to the normal control (Fig. 4B). 

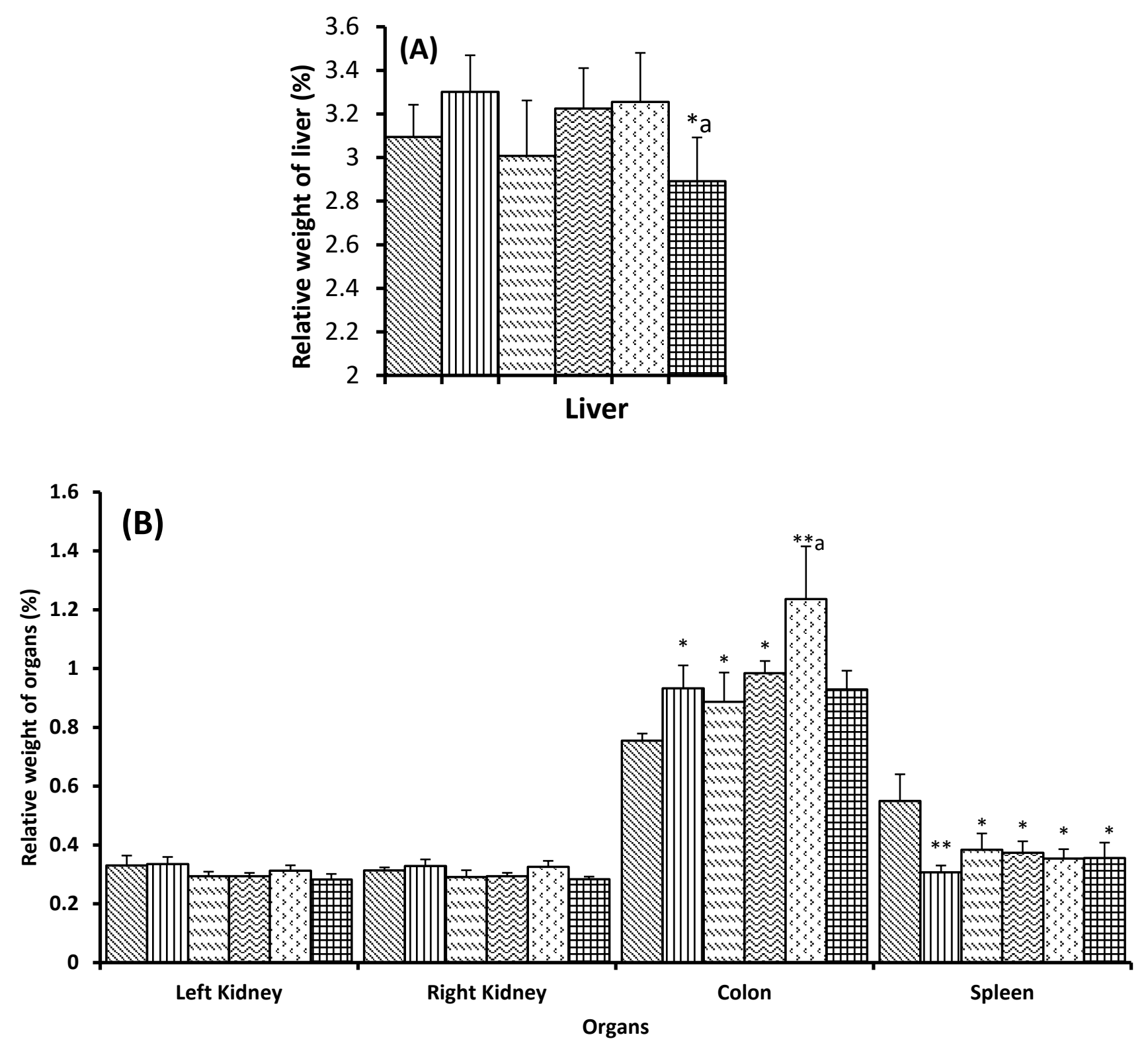

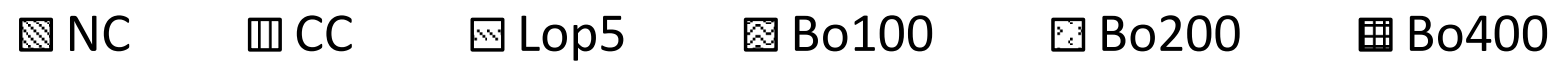

Fig. 4: Relative weights of liver (A), left kidney, right kidney, colon and spleen (B) in normal rats (NC), control colitis (CC) and rats treated with loperamide (Lop5) and hydroethanolic extract of Bixa orellana at 100 (Bo100), 200 (Bo200) and 400 (Bo400) $\mathrm{mg} / \mathrm{kg}$ bw. $\mathrm{n}=6$. Significant difference: ${ }^{*} \mathrm{P}<0.05 ;{ }^{* *} \mathrm{P}<0.01$ between $\mathrm{NC}$ and other groups; ${ }^{\mathrm{P}} \mathrm{P}<0.05$; ${ }^{\mathrm{b}} \mathrm{P}<0.01$ between $\mathrm{CC}$ and treated groups.

3.5. Effect of hydroethanolic extract of Bixa orellana leaves on hematological, leukocyte and platelet parameters

The hematological parameters, red blood cells (RBCs), hemoglobin $(\mathrm{Hb})$, hematocrit (Ht) for the normal control group were found to be $4.05 \pm 0.19 \times 10^{6} / \mu \mathrm{L}, 13.15 \pm 0.66 \mathrm{~g} / \mathrm{dL}$ and $38.65 \pm 1.92 \%$, respectively. In a colitis control group, a non-significant decrease $(\mathrm{P}>0.05)$ in these values $\left(3.93 \pm 0.14 \times 10^{6} / \mu \mathrm{L}, 13.02 \pm 0.49 \mathrm{~g} / \mathrm{dL}\right.$ and $38.35 \pm 1.37 \%$ ) was observed. In animals treated with loperamide $5 \mathrm{mg} / \mathrm{kg}$ or with the extract at doses of 100 and $400 \mathrm{mg} / \mathrm{kg}$, a significant increase $(\mathrm{P} \leq 0.05)$ in $\mathrm{RBCs}, \mathrm{Hb}$ and $\mathrm{Ht}$ compared to $\mathrm{NC}$ and $\mathrm{CC}$ was observed. 
However, the extract at $200 \mathrm{mg} / \mathrm{kg}$ showed no significant difference. Regarding the values of mean corpuscular volume (MCV), the mean corpuscular hemoglobin $(\mathrm{MCH})$, the mean corpuscular hemoglobin concentration (MCHC), no significant difference was observed between the different groups (Table 1).

Total white blood cells (WBCs), neutrophils and eosinophils for normal group were found to be $4.48 \pm 0.18 \times 10^{3} / \mu \mathrm{L}, 29.33 \pm 3.30 \%$ and $2.33 \pm 0.42 \%$, respectively. These values were significantly $(\mathrm{P}<0.05)$ decreased in the colitis control group. However, in the positive control group, the level of circulating neutrophils $(56.83 \pm 1.90 \%)$ increased significantly $(\mathrm{P}<0.01)$ compared to normal and colitis control groups. No significant difference $(\mathrm{P}>0.05)$ was observed between the different groups in the monocytes and basophils levels. The number of lymphocytes was significantly increased $(\mathrm{P}<0.01)$ in colitis control group $(75.16 \pm 3.30 \%)$ compared to the normal control $(67.83 \pm 3.27 \%)$. In contrast, loperamide induced a significant decrease in lymphocytes $(40.16 \pm 1.81 \%, \mathrm{P}<0.01)$ compared to NC and CC (Table 1$)$.

The platelet count (PIt) was $43.62 \pm 0.69 \times 10^{6} / \mu \mathrm{L}$ in the normal control and $38.72 \pm 1.61 \times 10^{6} / \mu \mathrm{L}(\mathrm{P}<0.01$ ) in the negative control. In animals treated with loperamide $\left(46.34 \pm 0.58 \times 10^{6} / \mu \mathrm{L} ; \mathrm{P}<0.01\right)$ and with the extract at different doses, no significant increase in platelets was observed (Table 1).

Table 1: Hematological, leukocyte and platelet parameters in normal rats (NC), the colitis control (CC) and rats treated with loperamide (Lop5) and with hydroethanolic extract of Bixa orellana at 100 (Bo100), 200 (Bo200) and 400 (Bo400) $\mathrm{mg} / \mathrm{kg}$ bw.

\begin{tabular}{|c|c|c|c|c|c|c|}
\hline & $\mathrm{NC}$ & $\mathbf{C C}$ & Lop5 & Bo100 & Bo200 & Bo400 \\
\hline RBC $\left(x 10^{6} / \mathrm{mm}^{3}\right)$ & $4.05 \pm 0.19$ & $3.93 \pm 0.14$ & $4.42 \pm 0.05$ & $4.77 \pm 0.14^{* \mathrm{~b}}$ & $4.07 \pm 0.10$ & $4.67 \pm 0.13^{* b}$ \\
\hline Hemoglobin (g/dL) & $13.15 \pm 0.66$ & $13.02 \pm 0.49$ & $14.18 \pm 0.17$ & $15.47 \pm 0.39 * \mathrm{~b}$ & $12.94 \pm 0.39$ & $14.24 \pm 0.19^{* \mathrm{a}}$ \\
\hline Hematocrit (\%) & $38.65 \pm 1.92$ & $38.35 \pm 1.37$ & $42.45 \pm 0.54$ & $46.20 \pm 1.63 * * \mathrm{~b}$ & $38.96 \pm 1.13$ & $42.96 \pm 2.13^{* \mathrm{a}}$ \\
\hline $\operatorname{MCV}\left(\mu \mathbf{m}^{3}\right)$ & $95.37 \pm 0.82$ & $97.52 \pm 0.92$ & $96.01 \pm 0.65$ & $96.84 \pm 1.15$ & $95.75 \pm 0.81$ & $94.65 \pm 0.71$ \\
\hline $\operatorname{MCHC}(g / d L)$ & $34.02 \pm 0.49$ & $33.94 \pm 0.52$ & $33.41 \pm 0.21$ & $33.55 \pm 0.58$ & $33.21 \pm 0.11$ & $33.61 \pm 0.21$ \\
\hline MCH (pg) & $32.45 \pm 0.53$ & $33.09 \pm 0.57$ & $32.08 \pm 0.16$ & $32.47 \pm 0.24$ & $31.79 \pm 0.35$ & $32.59 \pm 0.45$ \\
\hline WBC $\left(x^{10} / \mathbf{m m}^{3}\right)$ & $4.48 \pm 0.18$ & $3.55 \pm 0.21^{*}$ & $4.65 \pm 0.08^{\mathrm{a}}$ & $4.28 \pm 0.37^{\mathrm{a}}$ & $4.32 \pm 0.14^{\mathrm{a}}$ & $4.42 \pm 0.12^{\mathrm{a}}$ \\
\hline Lymphocytes (\%) & $67.83 \pm 3.27$ & $75.16 \pm 3.30$ & $40.16 \pm 1.81^{* * b}$ & $68.66 \pm 1.96^{\mathrm{a}}$ & $63.40 \pm 2.09^{\mathrm{a}}$ & $67.40 \pm 2.09^{\mathrm{a}}$ \\
\hline Monocytes (\%) & $0.16 \pm 0.16$ & $0.16 \pm 0.16$ & $0.50 \pm 0.34$ & $0.16 \pm 0.16$ & $0.60 \pm 0.36$ & $0.30 \pm 0.16$ \\
\hline Neutrophils (\%) & $29.33 \pm 3.30$ & $23.00 \pm 2.78^{* *}$ & $56.83 \pm 1.90^{* * \mathrm{~b}}$ & $29.50 \pm 2.14$ & $33.60 \pm 2.33^{\mathrm{a}}$ & $30.60 \pm 2.33$ \\
\hline Eosinophils (\%) & $2.33 \pm 0.42$ & $1.16 \pm 0.40^{*}$ & $2.00 \pm 0.45$ & $1.00 \pm 0.36^{*}$ & $1.80 \pm 0.34$ & $1.84 \pm 0.34$ \\
\hline Basophils (\%) & $0.33 \pm 0.21$ & $0.50 \pm 0.22$ & $0.50 \pm 0.22$ & $0.67 \pm 0.21$ & $0.60 \pm 0.22$ & $0.51 \pm 0.22$ \\
\hline 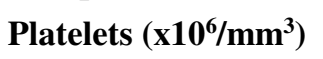 & $43.62 \pm 0.69$ & $38.72 \pm 1.61^{*}$ & $46.34 \pm 0.58^{b}$ & $40.46 \pm 1.50$ & $42.71 \pm 1.17$ & $41.72 \pm 1.12$ \\
\hline
\end{tabular}

Values are means \pm Standard Errors of Mean (ESM). $(\mathrm{n}=6)$ Significant difference: ${ }^{*} \mathrm{P}<0.05 ;{ }^{* *} \mathrm{P}<0.01$ between $\mathrm{NC}$ and other groups; ${ }^{\mathrm{a}} \mathrm{P}<0.05$; ${ }^{\mathrm{b}} \mathrm{P}<0.01$ between $\mathrm{CC}$ and treated groups.

\subsection{Effects of Bixa orellana hydroethanolic extract on oxidative stress parameters}

The SOD activity of the colitis control group was significantly ( $\mathrm{P}<0.01)$ decreased in serum $(-21.12 \%)$, liver $(-$ $29.61 \%)$, colon $(-19.46 \%)$ and in the kidneys $(-29.06 \%)$ compared to the normal control. The extract at different doses caused a significant increase in SOD activity in serum and in organs, but with a more remarkable increase in the liver $(+42.18 \%, \mathrm{P}<0.01)$ at $400 \mathrm{mg} / \mathrm{kg}$ compared to the colitis control (Table 2). 
Catalase activity was significantly $(\mathrm{P}<0.01)$ decreased in serum $(-70.58 \%)$, in the liver $(-32.41 \%)$, in the colon $(-$ $46.58 \%)$ and in the kidneys $(-40,60 \%)$ in the colitis control compared to the normal control. The hydroethanolic extract of B. orellana at different doses significantly increased the catalase activity in the serum and in the organs, but with a more remarkable increase in the blood $(+175.32 \%, \mathrm{P}<0.01)$ at $400 \mathrm{mg} / \mathrm{kg}$ bw compared to the colitis control (Table 2).

GSH concentrations of the negative control were significant $(\mathrm{P}<0.01)$ decreased in serum $(-49.39 \%)$, liver $(-$ $20.84 \%)$, colon $(-44.28 \%)$ and kidneys (-26.13\%) compared to normal control. Administration of the hydroethanolic extract of $B$. orellana at different doses resulted in a significant $(\mathrm{P}<0.05)$ increase in the GSH level in blood and organs in rats compared to the negative control (Table 2).

The concentration of malondialdehyde (MDA) significantly increased $(\mathrm{P}<0.01)$ in serum $(+830.33 \%)$, in the liver $(+142.63 \%)$, in colon $(+154.91 \%)$ and in the kidneys $(+80.21 \%)$ of colitis control rats compared to normal rats. The hydroethanolic extract of Bixa Orellana in different doses caused a significant decrease $(\mathrm{P}<0.05)$ in the level of MDA in the serum, in the liver, in the colon and in the kidneys compared to the negative controls (Table 2).

Table 2: Activities of superoxide dismutase (SOD) and catalase and levels of reduced glutathione (GSH) and malonedialdehyde (MDA) in serum, liver, colon and kidney of normal rats (NC), the control colitis (CC) and rats treated with loperamide (Lop5) and hydroethanolic extract of Bixa orellana at 100 (Bo100), 200 (Bo200) and $400(\mathrm{Bo} 400) \mathrm{mg} / \mathrm{kg}$ bw.

\begin{tabular}{|c|c|c|c|c|c|c|c|}
\hline Tissues & Parameters & $\mathrm{NC}$ & $\mathrm{CC}$ & Lop5 & Bo100 & Bo200 & Bo400 \\
\hline \multirow{4}{*}{ Serum } & SOD (UI/L) & $17.33 \pm 0.21$ & $13.67 \pm 0.21^{*}$ & $15.67 \pm 0.21^{* a}$ & $15.50 \pm 0.34^{* a}$ & $17.00 \pm 0.25^{\mathrm{b}}$ & $17.50 \pm 0.22^{\mathrm{b}}$ \\
\hline & $\begin{array}{l}\text { Catalase } \\
(\mathrm{mmol} / \mathrm{L})\end{array}$ & $52.62 \pm 1.70$ & $15.47 \pm 1.07^{* *}$ & $52.85 \pm 2.47^{\mathrm{b}}$ & $15.71 \pm 0.52^{* *}$ & $41.43 \pm 2.05^{* b}$ & $42.62 \pm 1.13^{* b}$ \\
\hline & GSH $(\mu \mathrm{mol} / \mathrm{L})$ & $58.98 \pm 1.08$ & $29.85 \pm 0.94^{* *}$ & $58.50 \pm 1.73^{\mathrm{b}}$ & $53.28 \pm 0.80^{* \mathrm{~b}}$ & $56.17 \pm 1.49^{\mathrm{b}}$ & $56.93 \pm 1.68^{\mathrm{b}}$ \\
\hline & $\operatorname{MDA}(\mu \mathrm{mol} / \mathrm{L})$ & $1.22 \pm 0.14$ & $11.35 \pm 0.64^{* *}$ & $2.88 \pm 0.09^{\mathrm{b}}$ & $5.99 \pm 0.05^{* a}$ & $2.06 \pm 0.05^{\mathrm{b}}$ & $1.58 \pm 0.14^{\mathrm{b}}$ \\
\hline \multirow{4}{*}{ Liver } & SOD (UI/g tissue) & $78.66 \pm 0.84$ & $55.33 \pm 1.23^{* *}$ & $62.00 \pm 0.89^{* * a}$ & $71.33 \pm 1.23^{* \mathrm{~b}}$ & $74.66 \pm 0.84^{\mathrm{b}}$ & $78.67 \pm 0.84^{\mathrm{b}}$ \\
\hline & $\begin{array}{l}\text { Catalase }(\mathrm{mmol} / \mathrm{g} \\
\text { tissue) }\end{array}$ & $514.28 \pm 10.43$ & $347.62 \pm 13.63^{* *}$ & $357.14 \pm 16.08^{* *}$ & $476.19 \pm 19.05^{b}$ & $520.00 \pm 11.89^{\mathrm{b}}$ & $519.04 \pm 17.16^{\mathrm{b}}$ \\
\hline & $\begin{array}{l}\mathrm{GSH}(\mu \mathrm{mol} / \mathrm{g} \\
\text { tissue) }\end{array}$ & $386.32 \pm 9.31$ & $305.78 \pm 2.33^{* *}$ & $331.91 \pm 10.23^{* * a}$ & $326.62 \pm 4.26^{* * a}$ & $324.26 \pm 10.04^{* * a}$ & $330.73 \pm 11.55^{* *_{a}}$ \\
\hline & $\begin{array}{l}\text { MDA }(\mu \mathrm{mol} / \mathrm{g} \\
\text { tissue) }\end{array}$ & $23.76 \pm 0.47$ & $57.65 \pm 0.78^{* *}$ & $33.89 \pm 0.33^{* b}$ & $20.77 \pm 0.87^{b}$ & $21.07 \pm 0.23^{b}$ & $16.92 \pm 0.88^{* b}$ \\
\hline \multirow{4}{*}{ Colon } & SOD (UI/g tissue) & $75.33 \pm 1.23$ & $60.67 \pm 1.23^{* *}$ & $66.00 \pm 0.89^{* * a}$ & $66.00 \pm 0.89^{* * a}$ & $74.66 \pm 1.68^{\mathrm{b}}$ & $78.00 \pm 0.89^{\mathrm{b}}$ \\
\hline & $\begin{array}{l}\text { Catalase }(\mathrm{mmol} / \mathrm{g} \\
\text { tissue) }\end{array}$ & $347.62 \pm 11.46$ & $185.71 \pm 6.39^{* *}$ & $347.62 \pm 11.46^{\mathrm{b}}$ & $228.57 \pm 7.37^{* a}$ & $233.33 \pm 8.78^{* a}$ & $333.33 \pm 15.93^{\mathrm{b}}$ \\
\hline & $\begin{array}{l}\mathrm{GSH}(\mu \mathrm{mol} / \mathrm{g} \\
\text { tissue) }\end{array}$ & $114.17 \pm 4.07$ & $63.63 \pm 3.04^{* *}$ & $107.59 \pm 3.86^{\mathrm{b}}$ & $71.71 \pm 2.81^{* * *}$ & $116.42 \pm 2.99^{b}$ & $116.52 \pm 3.42^{b}$ \\
\hline & $\begin{array}{l}\text { MDA }(\mu \mathrm{mol} / \mathrm{g} \\
\text { tissue) }\end{array}$ & $16.28 \pm 0.91$ & $41.49 \pm 1.53^{* *}$ & $15.04 \pm 0.96^{\mathrm{b}}$ & $21.62 \pm 1.23^{\mathrm{a}}$ & $12.35 \pm 0.66^{* b}$ & $14.57 \pm 1.24^{\mathrm{b}}$ \\
\hline \multirow{4}{*}{ Kidney } & SOD (UI/g tissue) & $78.00 \pm 0.89$ & $55.33 \pm 1.23^{* *}$ & $64.00 \pm 1.03^{* * a}$ & $65.33 \pm 0.84^{* * a}$ & $70.00 \pm 0.89^{* b}$ & $74.00 \pm 1.36^{\mathrm{b}}$ \\
\hline & $\begin{array}{l}\text { Catalase }(\mathrm{mmol} / \mathrm{g} \\
\text { tissue) }\end{array}$ & $328.57 \pm 9.76$ & $195.24 \pm 4.76^{* *}$ & $333.33 \pm 6.02^{\mathrm{b}}$ & $271.43 \pm 6.39^{* a}$ & $323.81 \pm 6.02^{\mathrm{b}}$ & $323.81 \pm 12.04^{\mathrm{b}}$ \\
\hline & $\begin{array}{l}\mathrm{GSH}(\mu \mathrm{mol} / \mathrm{g} \\
\text { tissue) }\end{array}$ & $280.49 \pm 5.86$ & $207.15 \pm 4.79^{* *}$ & $244.17 \pm 6.54^{* a}$ & $249.90 \pm 4.48^{* a}$ & $271.22 \pm 0.93^{\mathrm{b}}$ & $262.20 \pm 9.18^{\mathrm{b}}$ \\
\hline & $\begin{array}{l}\text { MDA }(\mu \mathrm{mol} / \mathrm{g} \\
\text { tissue) }\end{array}$ & $19.40 \pm 0.63$ & $34.96 \pm 0.66^{* *}$ & $22.11 \pm 0.27^{\mathrm{b}}$ & $20.89 \pm 0.56^{\mathrm{b}}$ & $17.31 \pm 0.25^{\mathrm{b}}$ & $19.02 \pm 0.78^{\mathrm{b}}$ \\
\hline
\end{tabular}

Values are means \pm Standard Errors of Mean $(\mathrm{ESM}) .(\mathrm{n}=6)$. Significant difference: ${ }^{*} \mathrm{P}<0.05 ;{ }^{* *} \mathrm{P}<0.01$ between $\mathrm{NC}$ and other groups; ${ }^{\mathrm{P}}<0.05$; ${ }^{\mathrm{b}} \mathrm{P}<0.01$ between $\mathrm{CC}$ and treated groups. 


\subsection{Effects of hydroethanolic extract of Bixa orellana on the pro-inflammatory parameter in rats}

The nitric oxide (NO) levels of the colitis control group were significantly increased $(\mathrm{P}<0.01)$ in the serum (+ $194.90 \%)$, in the liver $(+26.80 \%)$, in the colon $(+161.48 \%)$ and in the kidneys $(+62.23 \%)$ compared to the normal control group. The hydroethanolic extract of Bixa orellana in different doses significantly $(\mathrm{P}<0.01)$ reduced NO levels in blood, liver, colon and kidneys compared to the colitis control (Fig. 5).
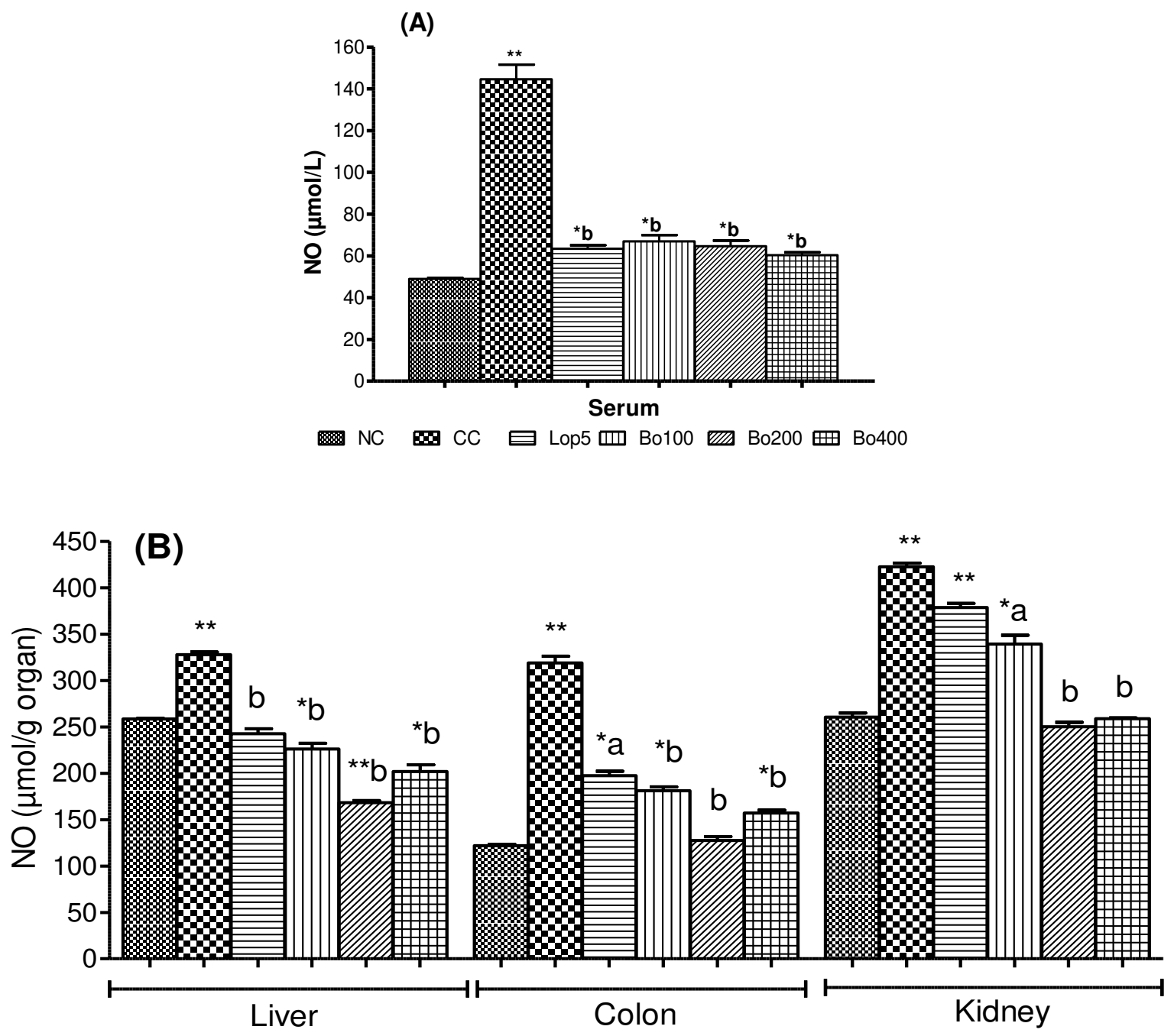

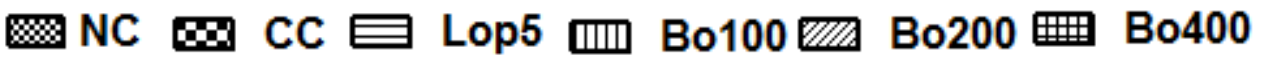

Fig. 5: Nitric oxide levels in the serum (A), liver, colon and kidney (B) of normal control (NC), the colitis control (CC) and rats treated with loperamide (Lop5) and hydroethanolic extract of Bixa orellana at 100 (Bo100), 200 (Bo200) and 400 (Bo400) mg/kg bw. $\mathrm{n}=6$. Significant difference: ${ }^{*} \mathrm{P}<0.05 ;{ }^{* *} \mathrm{P}<0.01$ between $\mathrm{NC}$ and other groups; ${ }^{\mathrm{P}}<0.05$; ${ }^{\mathrm{b}} \mathrm{P}<0.01$ between $\mathrm{CC}$ and treated groups.

3.7. Effect of the hydroethanolic extract of the leaves of Bixa orellana on the histopathology of the colon and the liver

Microscopic observation of colon sections of the normal control (NC) group showed intact epithelium without damage (Fig. 6A). The inflamed colon in the negative control group showed an inflammatory granuloma in the submucosa (Fig. 6B). In all other treated groups, the colon wall showed no pronounced damage. 

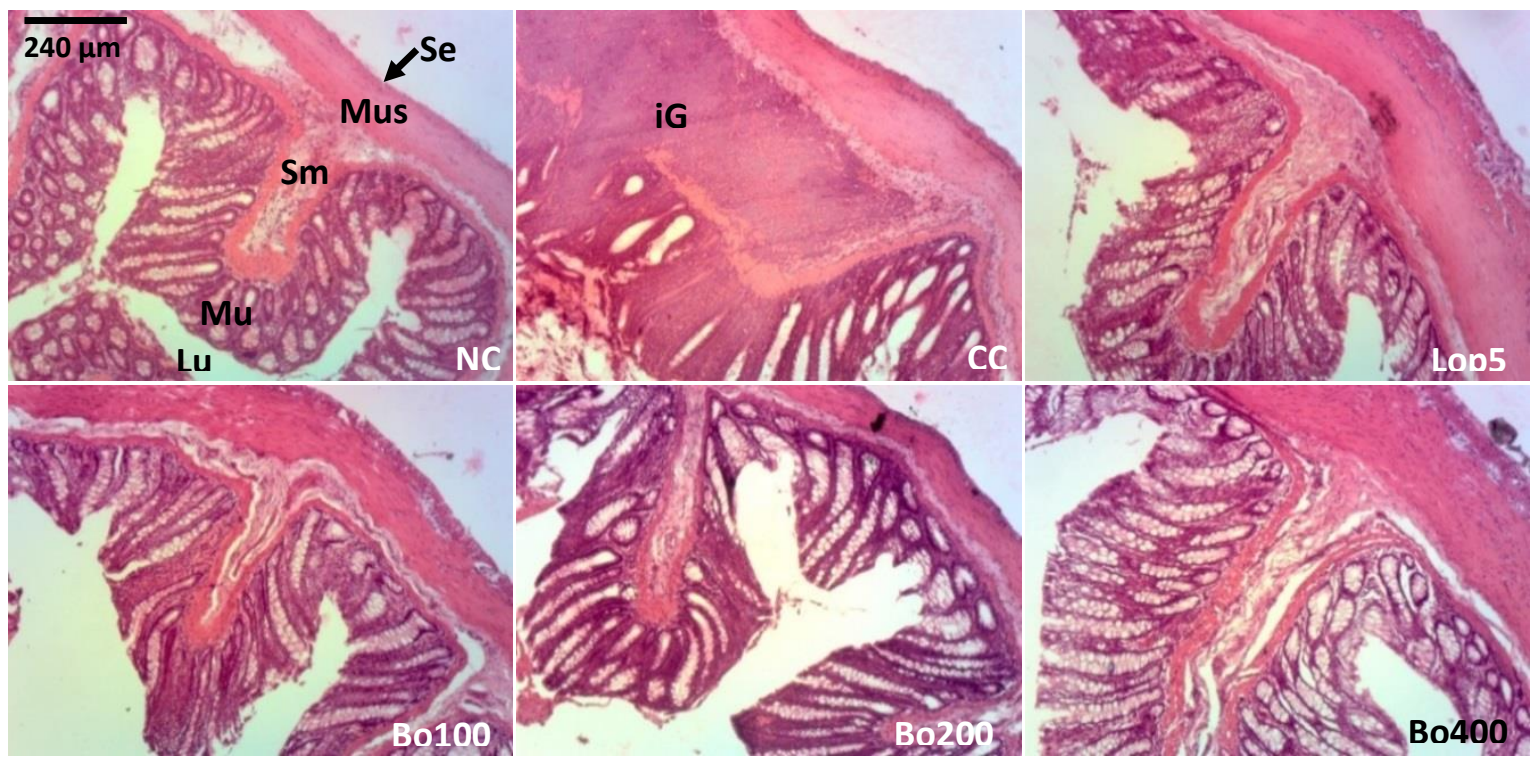

Fig. 6: Micrograph of colon (H\&E X 40) of normal control (NC), the colitis control (CC) and rats treated with loperamide (Lop5) and hydroethanolic extract of Bixa orellana at 100 (Bo100), 200 (Bo200) and 400 (Bo400) mg/kg bw. Lu: Intestinal lumen; Mu: Mucosa; Sm: submucosa; Mus: Muscular; Se: Serious; iG: Inflammatory granuloma.

A microscopic examination of histological sections of the liver in normal control (NC) and rats treated with loperamide (Lop5), extract at 100, 200 and $400 \mathrm{mg} / \mathrm{kg}$ shows normal liver parenchyma with a portal space, consisting of portal vein (pv), bile canaliculus (bc) and hepatic artery (ha), hepatocytes (He) arranged in a block and sinusoid capillaries (sc). The colitis control group (CC) presented pathological signs marked by leukocyte infiltration (li) (Fig. 7).
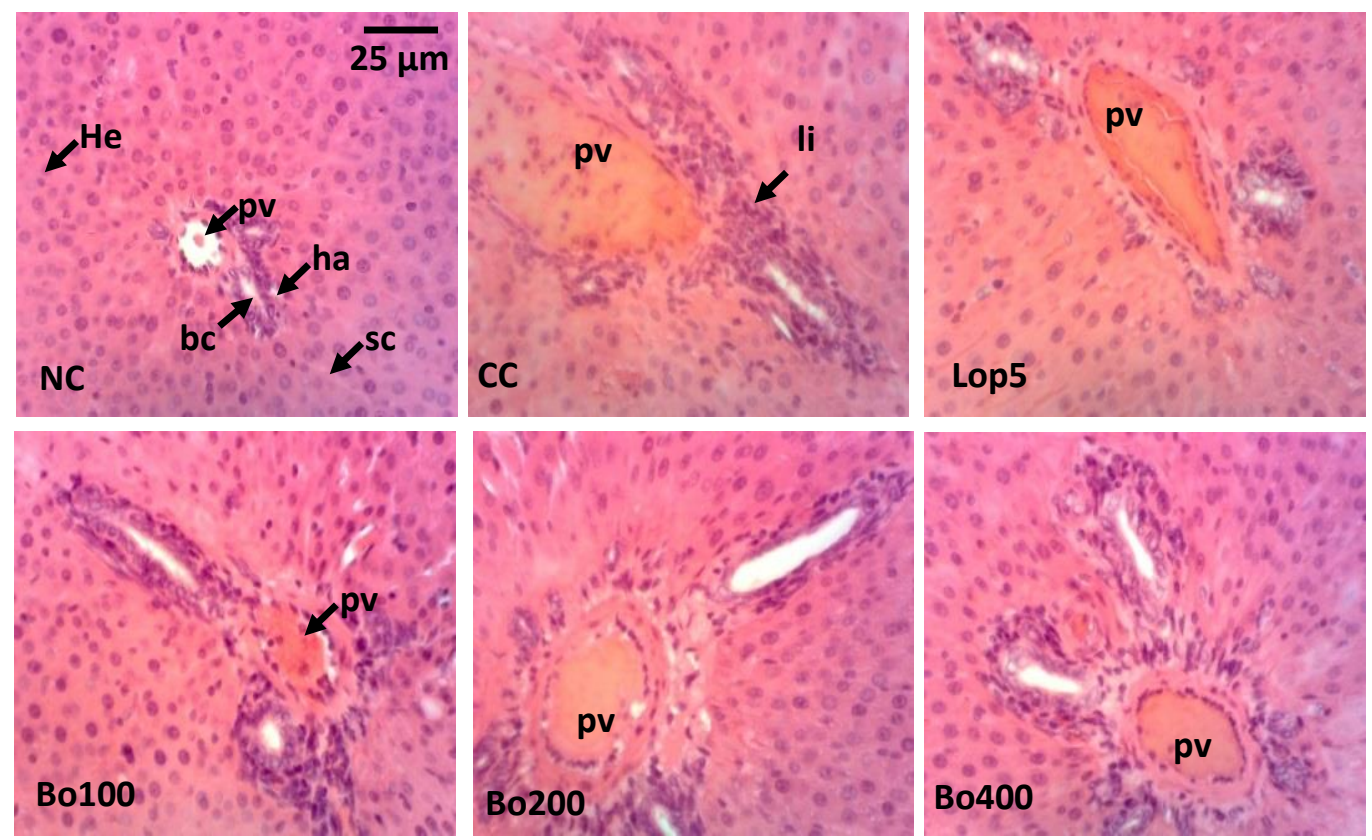

Fig. 7: Photomicrographs (H\&E X 40) of the liver of of normal control (NC), the colitis control (CC) and rats treated with loperamide (Lop5) and hydroethanolic extract of Bixa orellana at 100 (Bo100), 200 (Bo200) and 400 (Bo400) $\mathrm{mg} / \mathrm{kg}$ bw. pv: portal vein; He: Hepatocyte; sc: Sinusoidal capillary; ha: hepatic artery; li: Leukocyte infiltration; bc: bile canaliculus. 


\section{Discussion}

We found in the model of experimental colitis induced by acetic acid, that the indices of inflammation were less pronounced in animals treated with different doses of Bixa orellana extract compared to the colitis control group. In this model, the reactive oxygen species, vasoactive amines and eicosanoids are involved in the destruction of the colon structure and the mucous barrier by chemical stimulation, increased vessel permeability, increased inflammatory mediators, and promotion of fibrin hydrolysis (Thippeswamy et al. 2011). Bloody and mucous diarrhea, weight loss, relative and linear colon weight, and inflamed colon ulcerations are considered reliable and sensitive indicators of the severity of ulcerative colitis (Fokam Tagne et al. 2021b; Fokam Tagne et al. 2021a). In the present study, treatment of acetic acid-induced colitis in rats with hydroethanolic extract of Bixa orellana significantly reduced the frequency of diarrhea, relative and linear colon weight, number of gross lesions, and limited body weight loss compared to colitis control, indicating its effectiveness against ulcerative colitis.

Inflammatory bowel diseases such as ulcerative colitis are associated with oxidative stress identified as one of the main contributors to its pathophysiology (Lenoir et al. 2012). Acetic acid releases protons into the intracellular space, causing massive intracellular acidification resulting in immense epithelial damage causing acute inflammation. This acute inflammation usually results in a decrease in the activity of superoxide dismutase (SOD), a decrease in the activity of catalase (CAT), a decrease in the level of reduced glutathione (GSH) and an increase in the level of malondialdehyde (MDA), a marker of lipid peroxidation. All these parameters are associated with the release of pro-inflammatory mediators, resulting in an increase in the nitric oxide concentration (Nita and Grzybowski 2016). Acetic acid is an exogenous compound, which by its aggressiveness creates reactive oxygen species (ROS) responsible for oxidative stress (Kovacic and Somanathan 2017). Induction of colitis in rats resulted in a significant decrease in SOD activity, catalase activity and GSH and an increase in MDA and nitrites. Acetic acid would therefore be a pro-oxidant, capable of increasing the activity of nicotinamide adenine dinucleotide phosphate (NADPH) oxidase, responsible for the formation of free radicals in the mitochondria. These free radicals are at the origin of the lipid peroxidation that generates MDA, and of the drop in the level of GSH, due to its use to neutralize said free radicals under the action of glutathione peroxidase (Miller et al. 2007). Treatment of colitis animals with hydroethanolic extract of Bixa orellana significantly increased SOD and catalase activities, GSH concentration and reduced MDA and nitrite concentrations. In the leaves of B.orellana, it was found flavonoids (7- apigenin bisulfate, 7-luteolin bisulfate, 8-bisulfate hypoletin), flavones, diterpenes (alkaloids, gallic acid), carotenoids (bixin, norbixin, orelin, $\beta$-carotene, lutein, cryptoxanthin, zeaxanthin), vitamins A, B and C (Ancheta Henríquez and Guzmán Santamaría 2011). These molecules can act in different ways in the processes of regulation of oxidative stress by direct capture of ROS or by inhibition of certain enzymes responsible for the production of ROS such as cyclooxygenase and lipooxygenase (Bartošiková et al. 2003).

One of the most common extra-intestinal complications and/or manifestations of ulcerative colitis is anemia due to iron deficiency (Rogler and Vavricka 2015; Kang et al. 2020). Acetic acid-induced ulcerative colitis has induced anemia characterized by a decrease in hemoglobin accompanied by a reduction in red blood cells and hematocrit and a decrease in total white blood cells and neutrophils. Acetic acid causes inflammation of the colon, preventing absorption of iron, which is a constituent of hemoglobin (Rogler and Vavricka 2015; Kang et al. 2020). These symptoms are alleviated by administration of Bixa orellana extract or loperamide. The extract 
via flavonoids (Baba et al. 2009) would inhibit intestinal inflammation, thus promoting iron absorption and stimulation of hematopoiesis.

\section{Conclusion}

The objective of our work was to evaluate the pharmacological properties of Bixa orellana leaves hydroethanolic extract on acetic acid-induced ulcerative colitis in rats. Current results suggest that the hydroethanolic extract of Bixa orellana leaves treats acetic acid-induced ulcerative colitis in rats and this curative effect may be due to its antioxidant and anti-inflammatory properties.

Acknowledgements The authors thank the Laboratory of Endocrinology and Radioisotopes, Institute of Medical Research and Medicinal Plants studies (IMPM), Yaoundé, Cameroon, for providing the necessary support for this study.

Funding This research did not receive any specific grant from funding agencies in the public, commercial, or not-for-profit sectors.

Data availability The data used to support the findings of this study are included within the article.

\section{Declarations}

Ethical Statement The research was carried out after ethical approval from the institutional committee of the Cameroonian Ministry of Scien- tific Research and Innovation on the guidelines of the European Union on Animal Care. The ethical reference number of our article is "CEE Council 86/60"

\section{References}

Ammoury RF, Ghishan FK (2012) Pathophysiology of Diarrhea and its Clinical Implications. In: Leonard R. Johnson, Fayez K. Ghishan, Jonathan D. Kaunitz, Juanita L. Merchant, Hamid M. Said JDW (ed) Physiology of the Gastrointestinal Tract, Fifth Edit. Elsevier Inc., pp 2183-2197

Ancheta Henríquez JR, Guzmán Santamaría MG (2011) Efecto citoprotector del extracto acuoso de hojas de Bixa orellana (achiote) en úlceras gástricas inducidas por indometacina en un modelo de ratones. UNIVERSIDAD DR. JOSÉ MATÍAS DELGADO RED BIBLIOTECARIA MATÍAS DERECHOS

Ankouane Andoulo F, Kowo M, Ngo Nonga B, Djapa R, Njoya O, Ngu Blackett K, Biwolé Sida M, Ndjitoyap Ndam E (2013) Indications, Results and Yield of Coloscopy in a Difficult Economic Environment: The Case of Cameroon. Heal Sci Dis 14:1-6

Baba H, Ohtsuka Y, Haruna H, Lee T, Nagata S, Maeda M, Yamashiro Y, Shimizu T (2009) Studies of antiinflammatory effects of Rooibos tea in rats. Pediatr Int 51:700-704 . https://doi.org/10.1111/j.1442200X.2009.02835.x

Bartošiková L, Nečas J, Suchÿ V, Kubínová R, Veselá D, Beneš L, Illek J, Šalplachta J, Florian T, Frydrych M, Klusáková J, Bartošík T, Fráňa L, Fráňa P, Dzúrová J (2003) Antioxidative Effects of Morine in IschemiaReperfusion of Kidneys in the Laboratory Rat. Acta Vet Brno 72:87-94

Cosnes J, Gower-Rousseau C, Seksik P, Cortot A (2011) Epidemiology and Natural History of Inflammatory Bowel Diseases. Gastroenterology 140:1785-1794.e4 . https://doi.org/10.1053/j.gastro.2011.01.055

Dibong SD, Mvogo Ottou PB, Vandi D, Ndjib RC, Monkam Tchamaha F, Mpondo Mpondo E (2015) Ethnobotanique des plantes médicinales antihémorroïdaires des marchés et villages du Centre et du Littoral Cameroun. J Appl Biosci 96:9072 - 9093 . https://doi.org/10.1109/CCA.2015.7320732

Ellman GL (1959) Tissue sulfhydryl groups. Arch Biochem Biophys 82:70-77 . https://doi.org/10.1016/0003- 
9861(59)90090-6

Fermor B, Haribabu B, Brice Weinberg J, Pisetsky DS, Guilak F (2001) Mechanical stress and nitric oxide influence leukotriene production in cartilage. Biochem Biophys Res Commun 285:806-810 . https://doi.org/10.1006/bbrc.2001.5237

Fokam Tagne MA, Akaou H, Noubissi PA, Foyet Fondjo A, Rékabi Y, Wambe H, Kamgang R, Essame Oyono J-L (2019) Effect of the Hydroethanolic Extract of Bixa orellana Linn (Bixaceae) Leaves on Castor OilInduced Diarrhea in Swiss Albino Mice. Gastroenterol Res Pract 2019:8 pages. https://doi.org/10.1155/2019/6963548

Fokam Tagne MA, Noubissi PA, Gaffo EF, Fankem GO, Ngakou Mukam J, Kamgang R, Essame Oyono J-L (2021a) Effects of aqueous extract of Anogeissus leiocarpus (DC) guill. Et Perr. (Combretaceae) leaves on acetic acid-induced ulcerative colitis in rats. Adv Tradit Med 10 Pages . https://doi.org/10.1007/s13596021-00572-9

Fokam Tagne MA, Tchoffo A, Noubissi PA, Mazo AG, Kom B, Ngakou Mukam J, Sokeng Dongmo S, Kamgang R (2021b) Effects of hydro - ethanolic extract of leaves of Maesa lanceolata (Mursinaceae) on acetic acid - induced ulcerative colitis in rats. Inflammopharmacology 13 pages . https://doi.org/10.1007/s10787-021-00825-8

Freeman HJ (2014) Natural history and long-term clinical course of Crohn's disease. World J Gastroenterol 20:31-36 . https://doi.org/10.3748/wjg.v20.i1.31

Gupta P (2016) Bixa orellana: A Review on phytochemistry, traditinal and Pharmacological Uses. World J Pharm Sci 4:500-510

Kamgang R, Youmbi Mboumi R, Foyet Fondjo A, Fokam Tagne MA, Mengue N'dillé GPR, Ngogang Yonkeu J (2008) Antihyperglycaemic potential of the water-ethanol extract of Kalanchoe crenata (Crassulaceae). J Nat Med 62:34-40 . https://doi.org/10.1007/s11418-007-0179-y

Kang EA, Chun J, Im JP, Lee HJ, Han K, Soh H, Park S, Kim JS (2020) Anemia is associated with the risk of Crohn's disease, not ulcerative colitis: A nationwide population-based cohort study. PLoS One 15:1-13 . https://doi.org/10.1371/journal.pone.0238244

Kovacic P, Somanathan R (2017) Relationship of Organic Acids to Reactive Oxygen Species and Oxidative Stress in Biochemistry and Drug. J Cell Dev Biol 1:6-7

Kozembrou Ngueto Kitte E (2019) Dosage pharmacologique de biothérapie dans les MICI: Quand, comment, que faire en pratique clinique? Université Mohammed V de Rabat, Faculté de Médecine et de Pharmacie

Lee AM, Mandaliya R, Mattar MC (2018) Induction of remission in moderate-to-severe steroid refractory ulcerative colitis using patient-driven non-pharmacologic therapy. Adv Integr Med 5:119-121. https://doi.org/10.1016/j.aimed.2018.03.006

Lenoir L, Joubert-zakeyh J, Texier O, Lamaison J-L, Vasson M, Felgines C (2012) Aloysia triphylla infusion protects rats against dextran sulfate sodium-induced colonic damage. J Sci Food Agric 92:1570-1572 . https://doi.org/10.1002/jsfa.5544

Miller AA, Drummond GR, Mast AE, Schmidt HHHW, Sobey CG (2007) Effect of gender on NADPH-oxidase activity, expression, and function in the cerebral circulation: Role of estrogen. Stroke 38:2142-2149 . https://doi.org/10.1161/STROKEAHA.106.477406

Misra HP, Fridovich I (1972) The role of superoxide anion in the autoxidation of epinephrine and a simple assay for superoxide dismutase. J Biol Chem 247:3170-3175

Nita M, Grzybowski A (2016) The Role of the Reactive Oxygen Species and Oxidative Stress in the Pathomechanism of the Age-Related Ocular Diseases and Other Pathologies of the Anterior and Posterior Eye Segments in Adults. Oxid Med Cell Longev 2016:23 Pages . https://doi.org/10.1155/2016/3164734

Rogler G, Vavricka S (2015) Anemia in inflammatory bowel disease: An under-estimated problem? Front Med 
Rufo PA, Bousvaros A (2006) Current therapy of inflammatory bowel disease in children. Pediatr Drugs 8:279302 . https://doi.org/10.2165/00148581-200608050-00002

Sinha AK (1972) Colorimetric assay of catalase. Anal Biochem 47:389-394 . https://doi.org/10.1016/00032697(72)90132-7

Smith J, van den Broek F, Martorel Jc, Hackbarth H, Ruksenas O, Zeller W (2007) FELASA Working Grp, and "Principles and Practice in Ethical Review of Animal Experiments across Europe: Summary of the Report of a Felasa Working Group on Ethical Evaluation of Animal Experiments." Lab Anim 41:143-160

Thippeswamy BS, Mahendran S, Biradar MI, Raj P, Srivastava K, Badami S, Veerapur VP (2011) Protective effect of embelin against acetic acid induced ulcerative colitis in rats. Eur J Pharmacol 654:100-105 . https://doi.org/10.1016/j.ejphar.2010.12.012

Wilbur KM, Bernheim F, Shapiro OW (1949) The thiobarbituric acid reagent as a test for the oxidation of unsaturated fatty acids by various agents. Arch Biochem 24:305-313

Yougbaré-Ziébrou MN, Ouédraogo N, Lompo M, Bationo H, Yaro B, Gnoula C, Sawadogo WR, Guissou IP (2016) Anti-inflammatory, analgesic and antioxidant activities of an aqueous extract of Saba senegalensis Pichon stems with leaves (Apocynaceae) M.N. Phytotherapie 14:213-219 https://doi.org/10.1007/s10298-015-0992-5 